\title{
DATING THE DEAD: NEW RADIOCARBON DATES FROM THE LOWER ICA VALLEY, SOUTH COAST PERU
}

\author{
Lauren Cadwallader ${ }^{1,2} \bullet$ Susana Arce Torres ${ }^{3} \bullet$ Tamsin C O’Connell $^{4} \cdot$ Alexander G Pullen $^{1} \bullet$ \\ David G Beresford-Jones ${ }^{1}$
}

\begin{abstract}
This article presents radiocarbon dates from human bone samples $(n=13)$ from seven pre-Columbian cemeteries in the Samaca and Ullujaya Basins of the lower Ica Valley, south coast of Peru, spanning from the end of the Early Horizon to the Inca Late Horizon. These contexts have been severely looted. Yet, in all cases, their putative dating by material culture remains is confirmed by these ${ }^{14} \mathrm{C}$ dates. This shows that such disturbed contexts, sadly typical of the Peruvian coast, can nonetheless still yield valuable bioarchaeological and burial practice data. These dates elaborate upon an emerging picture of the absolute dating of the cultural phases of the wider south coast region, in particular casting new light on the poorly understood Middle Horizon to Late Intermediate period transition. A paucity of archaeological data for this 3-century period has been taken as evidence of some sort of environmentally or socially induced lacuna. Instead, the ${ }^{14} \mathrm{C}$ dates presented here suggest that the basins of the lower Ica Valley were continuously occupied over this period.
\end{abstract}

\section{INTRODUCTION}

The riverine oases that cross the arid desert of the south coast of Peru were host to a rich history of cultural change. Over more than 2 millennia before the Spanish conquest (about $750 \mathrm{BC}$ to AD 1536), at least six major cultural changes occurred here. The Paracas (or Ocucaje) culture emerged in the Early Horizon, duly to evolve into Nasca. Nasca's fragmentation and collapse was followed by domination of the region by the highland Wari Empire during the Middle Horizon before, in turn it waned and the more regionally focused Ica-Chincha society flourished before being incorporated into the Inca Empire.

Much of the archaeological work has focused on the valleys of the Río Grande de Nazca. Yet, the Ica Valley, just to the north, also had a significant, and sometimes dominant, role to play in the cultural trajectories of the south coast. Moreover, ceramic sequences from Ica (Menzel 1964, 1976; Menzel et al. 1964) underlie Rowe's (1967) widely used chronology for all Andean prehistory. Parts of those sequences are only now being tied to absolute radiocarbon dates on the south coast based on work in Nazca and Palpa (Unkel and Kromer 2009; Unkel et al. 2012), while others still remain to be clarified or refined (and see Vaughn et al. 2014). This study is the first to assess the ceramic chronology using ${ }^{14} \mathrm{C}$-dated material from the Ica Valley itself.

Our study area is the Samaca and Ullujaya Basins of lower Ica Valley (see Figure 1). Along the western margins of these basins lie the cemeteries of the various cultural groups who inhabited them over some $2000 \mathrm{yr}$. We report dates from a selected subset of seven cemeteries-four in the Samaca Basin and three in Ullujaya - out of a total of 34 such funerary contexts recorded here (Beresford-Jones 2011). All have been subjected to severe looting throughout the 20th century by huaqueros to supply pre-Columbian "art" markets (see Pollard Rowe 1979, 1992; Burger 1992; Metropolitan Museum of Art 2013), and their surfaces are littered with fragments of material culture and human remains and other looting debris. Investigations of human remains from those looted contexts have yielded valuable information on changes in ancient diet from the Early Horizon through to the end of the Late Intermediate Period (see Cadwallader 2013). Without secure dating, however, the inferences that can be drawn about these individuals and the communities to which they belonged will inevitably be subject to the caveats entailed by their looted contexts. Thus, the

1. McDonald Institute for Archaeological Research, University of Cambridge, Downing Street, Cambridge, CB2 3ER, UK. 2. Corresponding author. Email: 1c340@cam.ac.uk.

3. Museo Regional de Ica (INC-Ica), Avda. Ayabaca s/n Cuadra 8, Urbanización San Isidro, Ica, Perú.

4. Department of Archaeology and Anthropology, University of Cambridge, Downing Street, Cambridge, CB2 3DZ; and McDonald Institute for Archaeological Research, University of Cambridge, Downing Street, Cambridge, CB2 3ER, UK. 
dates we present serve also to confirm the putative archaeological associations of these various looted cemeteries and thus provide a secure chronological framework for this bioarchaeological data.

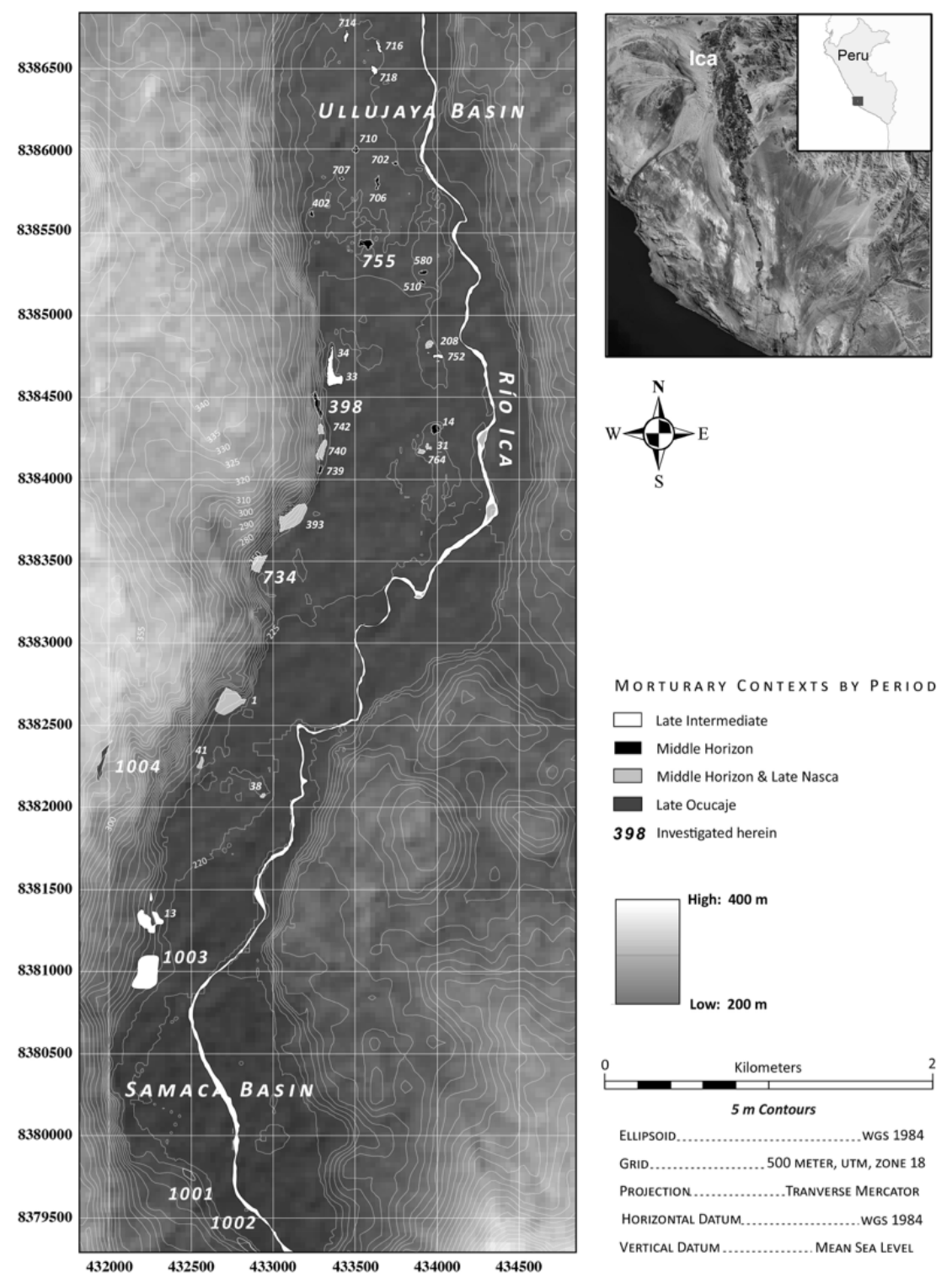

Figure 1 Map of the archaeology of the Samaca and Ullujaya Basins, lower Ica Valley, south coast Peru, highlighting the seven funerary contexts dated.

\section{MATERIALS AND METHODS}

Seven cemetery sites were initially dated based on their associated material culture remains (see Table 1). Diagnostic ceramics that could be used to date the cemeteries were gathered during the systematic field-walking surveys for the purpose of collecting human and faunal remains for paleodietary investigations (Cadwallader 2013). Other aspects of funerary architecture, grave goods, etc., were also recorded through archaeological survey (Beresford-Jones 2011; Cadwallader 2013). 
Table 1 Details of the cemeteries chosen for dating and their assigned periods based on the ceramic assemblage collected from the surface.

\begin{tabular}{|c|c|c|c|}
\hline Cemetery & Location & Ceramic phases & Assigned period \\
\hline 1001 & Samaca & Ocucaje $9,10^{\mathrm{a}}$ & Late Ocucaje-Initial Nasca \\
\hline 1002 & Samaca & Ocucaje 9,10 (\& few fragments of Early Nasca $)^{a}$ & Late Ocucaje-Initial Nasca \\
\hline 1004 & Samaca & $\begin{array}{l}\text { Ocucaje } 9,10 \text {, Nasca } 1 \text { ( \& few fragment of Early } \\
\text { Nasca phases } 2 / 3)^{\mathrm{a}}\end{array}$ & Late Ocucaje-Initial Nasca \\
\hline 734 & Ullujaya & Nasca 7, 8 (Dawson Phases) & Late Nasca \\
\hline 398 & Ullujaya & Nasca 7/8, Middle Horizon Epoch $2^{\mathrm{a}}$ & Middle Horizon \\
\hline 755 & Ullujaya & $\begin{array}{l}\text { Middle Horizon Epoch 2B, } 4 \text { (\& few fragments of } \\
\text { Late Intermediate Period ceramics) })^{\mathrm{a}, \mathrm{b}, \mathrm{c}, \mathrm{d}, \mathrm{e}}\end{array}$ & Middle Horizon \\
\hline 1003 & Samaca & Few Middle Horizon Epoch 4, Ica Phases 6-10 $0^{\mathrm{e}, \mathrm{f}}$ & Late Intermediate Period \\
\hline
\end{tabular}

Human remains were collected for analysis from these cemeteries by choosing, where possible, well-preserved crania so as to obtain both age and sex information for each individual (see Cadwallader 2013). A subsample of 15 individuals was selected for ${ }^{14} \mathrm{C}$ analysis, comprising males and females (Table 2). These individuals were chosen according to their good collagen preservation, adult age, and isotopic results. The latter suggest little, if any, marine resource consumption because $\delta^{15} \mathrm{~N}$ values are not greatly elevated, while higher $\delta^{13} \mathrm{C}$ values are likely due to high direct and indirect consumption of $\mathrm{C}_{4}$ plants: in particular maize, a dietary staple in the region during most of these time periods (see Buzon et al. 2012; Cadwallader et al. 2012; Cadwallader 2013). Thus, these ${ }^{14} \mathrm{C}$ values cannot be influenced by a marine reservoir effect known to be significant along the Peruvian coast (Jones et al. 2010).

Table 2 Details of individuals chosen for ${ }^{14} \mathrm{C}$ dating. Age, sex, and isotopic information (including collagen yield) is taken from Cadwallader (2013).

\begin{tabular}{|c|c|c|c|c|c|c|c|}
\hline Cemetery & Individual & $\operatorname{Sex}^{\mathrm{a}}$ & Age (yr) & $\delta^{13} \mathrm{C}(\%)$ & $\delta^{15} \mathrm{~N}(\%)$ & Atomic $\mathrm{C}: \mathrm{N}$ ratio & Collagen yield \\
\hline 1001 & 54 & $\mathrm{U}$ & $36-45$ & -17.5 & 9.2 & 3.5 & $10 \%$ \\
\hline 1001 & 57 & M & $46-59$ & -17.3 & 9.4 & 3.5 & $13 \%$ \\
\hline 1002 & 117 & $\mathrm{~F}$ ? & $46-59$ & -16.5 & 8.3 & 3.2 & $21 \%$ \\
\hline 1002 & 118 & M? & $36-45$ & -13.7 & 10.7 & 3.3 & $20 \%$ \\
\hline 1004 & 63 & $\mathrm{U}$ & $36-45$ & -14.2 & 10.1 & 3.4 & $16 \%$ \\
\hline 1004 & 66 & $\mathrm{~F}$ & $26-35$ & -15.8 & 8.1 & 3.4 & $23 \%$ \\
\hline 1004 & 69 & M? & $18-25$ & -15.7 & 8.5 & 3.3 & $21 \%$ \\
\hline 734 & 9 & $\mathrm{~F} ?$ & $26-35$ & -14.2 & 8.8 & 3.2 & $19 \%$ \\
\hline 734 & 14 & $\mathrm{U}$ & Adult & -15.3 & 9.1 & 3.2 & $24 \%$ \\
\hline 398 & 91 & M? & $36-45$ & -13.4 & 9.7 & 3.1 & $20 \%$ \\
\hline 398 & 101 & $\mathrm{~F}$ & $26-35$ & -13.7 & 9.5 & 3.2 & $20 \%$ \\
\hline 755 & 53 & M? & $26-35$ & -9.8 & 8.8 & 3.2 & $22 \%$ \\
\hline 755 & 83 & $\mathrm{~F}$ ? & $26-35$ & -13.2 & 8.3 & 3.2 & $17 \%$ \\
\hline 1003 & 31 & M & $36-45$ & -10.4 & 9.6 & 3.1 & $19 \%$ \\
\hline 1003 & 74 & $\mathrm{~F}$ & $18-25$ & -10.1 & 9.4 & 3.2 & $19 \%$ \\
\hline
\end{tabular}

${ }^{\mathrm{a}} \mathrm{M}=$ Male; M?=Probable male; F=Female; F?=Probable female; U=Unknown sex.

${ }^{14} \mathrm{C}$ dating was carried out by the Oxford University Radiocarbon Accelerator Unit, in the Research Laboratory for Archaeology and the History of Art, Oxford. Thirteen out of the 15 samples pro- 
duced collagen in sufficient quantity and quality to be dated (see Table 3). The two samples that failed were both from Cemetery 1001. For details of sample preparation and AMS measurements, see Brock et al. (2010).

\section{CALIBRATION}

The study area lies at $14^{\circ} \mathrm{S}$, below and to the west of the southern limit of the intertropical convergence zone (ITCZ). The most recent ${ }^{14} \mathrm{C}$ calibration for the Southern Hemisphere, SHCal13 (Hogg et al. 2013) has been constructed for samples originating to the south of the ITCZ and so could be used here, as it has for many other (e.g. Brown Vega et al. 2012; Grobman et al. 2012), though not all (e.g. Marsh 2012), Andean data sets. The closest dated materials to the lower Ica Valley from sites in the Palpa Valley (Unkel et al. 2012) about $60 \mathrm{~km}$ south were, however, calibrated using the Northern Hemisphere calibration IntCal09 curve (Reimer et al. 2009), with a Southern Hemisphere correction of $41 \pm 14 \mathrm{yr}$ (McCormac et al. 2002).

The SHCal13 calibration curve is offset from its Northern Hemisphere equivalent curve, IntCal13, by a mean of $43 \pm 23 \mathrm{yr}$ (Hogg et al. 2013), which means that the difference between the two curves is almost inevitably less than the duration of any particular ceramic period. The use of the IntCal13 curve (Reimer et al. 2013) together with the application of a correction has the effect of reducing the wiggles in the resulting ${ }^{14} \mathrm{C}$ calibration curve and thus produces dates with tighter ranges than SHCal13. The correction of $40 \pm 20 \mathrm{yr}$ suggested by Hogg et al. (2009) for the Southern Hemisphere could also be applied to IntCal13. However, both of these corrections for SHCal13 are based on data of a non-Andean origin.

While the use of the Northern Hemisphere calibration curves has been shown to ${ }^{14} \mathrm{C}$ date trees from the tropics well (Worbes and Junk 1989) as carbon cycles in both hemispheres are similar (Hua et al. 2000), the suitability of using the IntCal curves with a correction for Andean dates has not been investigated. Arguments, therefore, can be made for calibration of ${ }^{14} \mathrm{C}$ dates from the lower Ica Valley using either curve and/or correction factor. But since few precedents exist to date for the south coast, we have chosen to present dates using both curves (SHCal13 and IntCal13 plus correction of $40 \pm 20 \mathrm{yr}$ ) in order to discuss these dates within the context of the best published data to date (Unkel et al. 2012). We use Hogg et al.'s (2009) correction factor, which is more recent than the McCormac et al. (2002) correction used by Unkel et al. (2012). OxCal version 4.2 (Bronk Ramsey 2009) was used to perform the calibrations.

Table 3 shows the modeled date calibrations for each sample using both curves, while Figure 2 illustrates these and the modeled boundaries for the periods calibrated using OxCal v 4.2 (Bronk Ramsey 2009). Table 4 shows the start and end dates for each period based on the median values of the boundaries for both calibration models. The boundary and phase functions in OxCal have been used to define timespans for the ${ }^{14} \mathrm{C}$ dates, as recommended by Bronk Ramsey (2001), and following Unkel et al. (2012).

The difference between the calibrated modeled dates using the two curves (SHCal and IntCal13 with a correction of $40 \pm 20 \mathrm{yr}$ ) is very small, with a maximum difference of $33 \mathrm{yr}$ between the median date for each individual. The maximum difference between the boundary dates for the phases produced by the two calibrations is $20 \mathrm{yr}$ (start of the Late Nasca) based on the median values (see Table 4). The difference between the curves observed for these dates is not substantial enough to affect significantly the ranges for the archaeological periods. Either curve could therefore be used for calibration, supporting the findings of Unkel et al. (2012). 


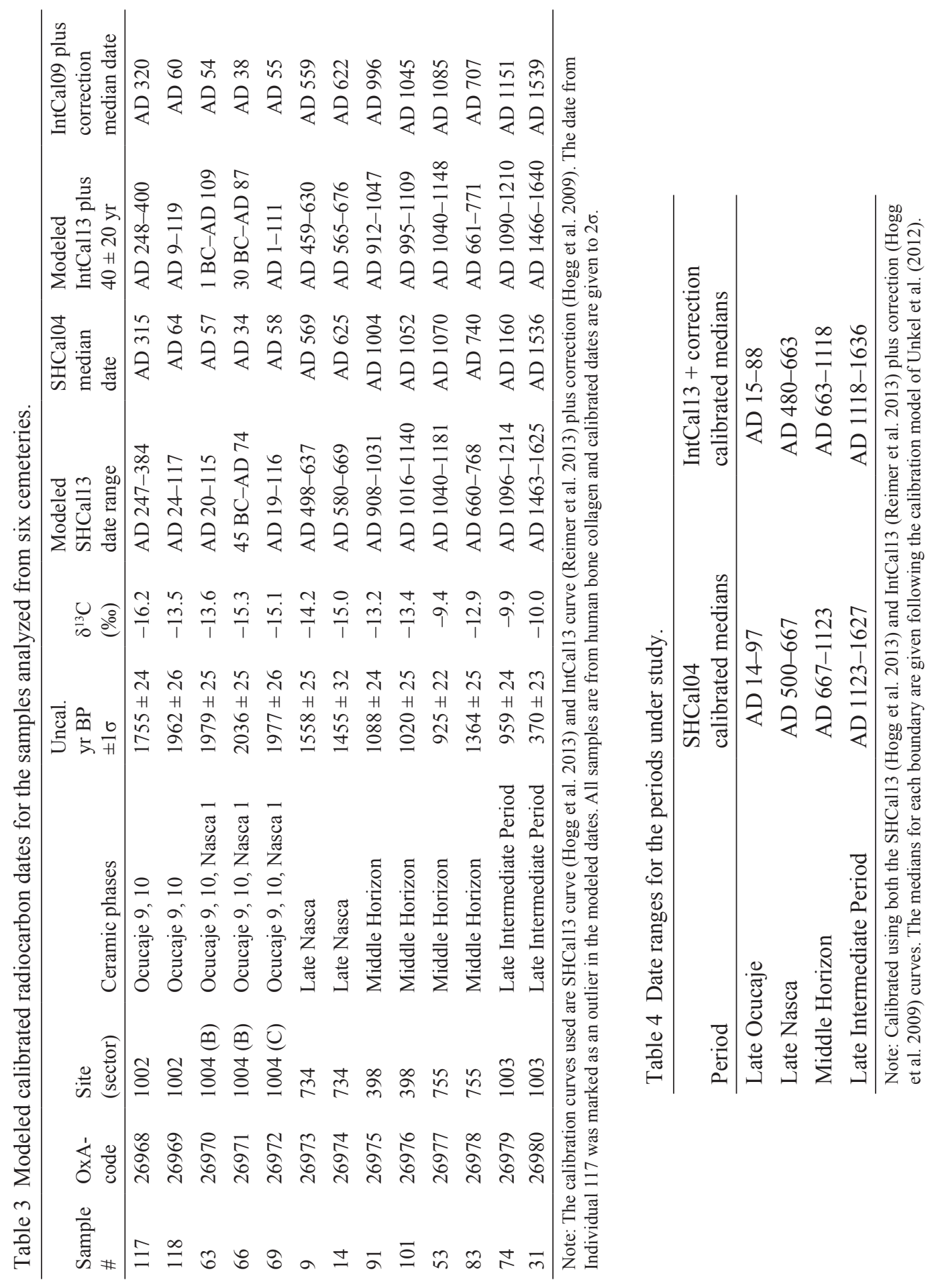


In order to be consistent and comparable with the largest published ${ }^{14} \mathrm{C}$ data set from the same region (Unkel et al. 2012), we will use the dates generated using the IntCal13 curve plus correction (Hogg et al. 2009) during the discussion and conclusion of this paper. Date ranges given in the following discussion are to $2 \sigma$.

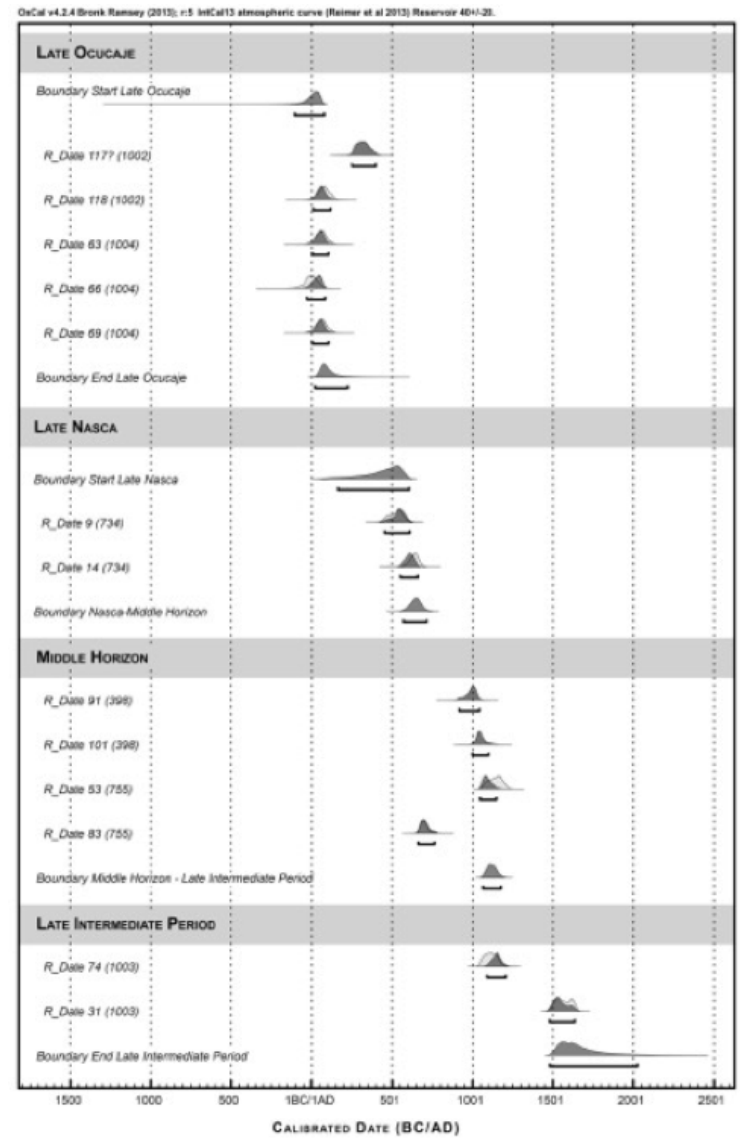

Figure 2 Calibrated ${ }^{14} \mathrm{C}$ dates from human bone samples from six of the cemeteries studied. The single date calibrations are given to the $2 \sigma$ range and were calibrated using OxCal v 4.2 (Bronk Ramsey 2009) and IntCal13 (Reimer et al. 2013) with a correction of $40 \pm 20 \mathrm{yr}$ (Hogg et al. 2009). The date produced by Sample 117 was not used to model the sum date for the Late Ocucaje period because it assumed to be intrusive (see text); hence, it is labeled here with a question mark.

\section{RESULTS AND DISCUSSION}

\section{Late Ocucaje-Nasca Transition (Cemeteries 1001, 1002, and 1004)}

Four of the five individuals dated from the two cemeteries of 1002 and 1004 fall into the period defined by Unkel et al. (2012:2299) as Initial Nasca (260 cal BC to cal AD 80; median boundary values), and correspond well with the material culture remains associated with their disturbed funerary contexts: principally from ceramic phases Ocucaje 9 and 10 (Menzel et al. 1964), together with a few Nasca 1 fragments at Cemetery 1004.

The date from one individual (Individual 117) from 1002 of cal AD 248-400 is later than the others, falling within Unkel et al.'s (2012:2299) definition of Early Nasca (cal AD 80-300) or Middle Nasca (cal AD 300-440). There are a few fragments of Early Nasca pottery recorded in 1002, as well as in context 1004, suggesting that these sites may also have been used for burial during that period. 
This is noteworthy, both because it suggests some cultural continuity between Late Ocucaje and Early Nasca, and because, although there are extensive Early Nasca archaeological remains in the Ullujaya Basin, funerary contexts from that period here are seemingly rather few (see BeresfordJones 2011). Indeed, iconographic similarities have long been read as suggesting gradual transition and shared cultural traits between Paracas and Nasca (Menzel et al. 1964). This transition has yet to be properly defined both in terms of sociopolitical factors entailed and absolute chronology (see Cadwallader et al., in press). These dates contribute to the latter (and see also Vaughn et al. 2014:Table 2).

\section{Late Nasca-Middle Horizon Transition (Cemetery 734)}

The two dated individuals from Cemetery 734 (cal AD 459-630 and 565-676) lie within Unkel et al.'s (2012:2299) definition of "Late Nasca" (cal AD 440-640). They therefore coincide with the material culture remains used originally to assign this disturbed funerary context to Nasca 6/7.

\section{Middle Horizon (Cemeteries 398 and 755)}

Several looted cemeteries in the lower Ica Valley are putatively dated to the Middle Horizon by their barbacoa architecture and material culture remains including pottery fragments from so-called "Nasca" phases 8 and 9 (or Chakipampa/Loro) and Middle Horizon Epoch 2 (Menzel 1964); together with materials variously assigned as Early Ica-Epigonal (Kroeber and Strong 1924), Chulpaca A (Pezzia Assereto 1968:230, 252-3), and Ica I (Lyons 1966), all of which we prefer conservatively to lump under Middle Horizon Epoch 4 (following Menzel 1964:65, 1976:1-5).

Four individuals were dated from two of these cemeteries, 398 and 755, the earliest of which (cal AD 661-771) falls into the time period defined for Nasca 9 or the start of the Middle Horizon on the south coast defined by Unkel et al. (2012). Three others, however, date to between cal AD 900 and 1150.

Where it arose in the Ayacucho highlands the Wari Empire is thought to have endured between around AD 550 and 1000 (Cook 2004:158). On the south coast, Unkel et al. (2012:2299) date the Wari Middle Horizon to between cal AD 640 and 790 (median boundary values) in Palpa, while Conlee (2010:99) dates it to between cal AD 650 and 830 in the Nazca Valley. After this, no ${ }^{14} \mathrm{C}$ dates have been reported from the south coast until around AD 1200, the widely accepted date for the start of the Late Intermediate Period here (Conlee 2010; Unkel et al. 2012:Figure 2). Yet, three individuals from these funerary contexts in the lower Ica Valley date to this time of transition between the fall of the Middle Horizon and the start of the Late Intermediate Period.

\section{Late Intermediate Period (Cemetery 1003)}

Cemetery 1003 was putatively attributed to the Late Intermediate Period/Late Horizon through associated pottery remains from Ica Phases 6 through 10 (Menzel 1976). There are few ${ }^{14} \mathrm{C}$ dates for the Late Intermediate on the south coast, though Unkel et al. (2012:2299) date its start to cal AD 1180. Two individuals ${ }^{14} \mathrm{C}$ dated from 1003 are separated by several hundred years. The earliest dates from cal AD 1090-1210, while the other dates to cal AD 1466-1640, lying therefore in the Inca Late Horizon, or even the early Colonial Period.

There are two Late Intermediate/Late Horizon settlement sites in the Samaca Basin, H-8 and H-9 (see Cook 1991; Beresford-Jones 2011), the latter almost adjacent to Cemetery 1003, where we presume the deceased of those sites were buried. These sites all show the same material culture palimpsests: pottery of Late Intermediate Ica 6, Chincha-influenced Ica 7 and 8, Late Horizon Ica 9 
and early Colonial Ica 10 (including, for instance, glass beads), when Ica culture, free of the Inca yoke and before the full onset of Spanish conquest, enjoyed a brief renaissance (Menzel 1976).

\section{CONCLUSIONS}

The ${ }^{14} \mathrm{C}$ dates in this study show good agreement with those published by Unkel et al. (2012) from the neighboring Palpa Valley, demonstrating continuity in the spatial and temporal distribution of material culture styles across the south coast region. In all cases, the putative assignation of these funerary contexts to particular culture epochs by their material culture remains is confirmed despite their violently looted conditions, which in turn, allows the direct evidence obtained from stable isotope analyses of human remains about ancient diet, mobility, and social distinctions (see Cadwallader 2013), to be placed securely within a chronological framework.

Finally, the dates from individuals from Cemeteries 398 and 755 call into question the widely held notion that the end of the Middle Horizon on the south coast was marked by a complete absence of settlement, perhaps occasioned by some sort of environmentally induced crisis, until the dawn of the Late Intermediate Period some 3 centuries later (see inter alia Conlee 2010; Eitel and Mächtle 2009; Unkel et al. 2012; Vaughn et al. 2014). There are other large funerary contexts in the Samaca and Ullujaya Basins of the lower Ica Valley, including Cemeteries 752 and 208 whose related architecture and related Middle Horizon 4 material culture suggest that these were occupied continuously during this period, whose chronology and culture history remains poorly understood. Together, these data imply that the echoes of Wari influence on the south coast may have lasted considerably longer than previously thought.

\section{ACKNOWLEDGMENTS}

We thank the Ministerio de Cultural del Perú for granting permission for the fieldwork (No. 0028-2010-VMPCIC-MC) and analysis of samples for dating (No. 369-2011-VMPCIC-MC); Alberto Benavides Ganoza and the people of Samaca for facilitating fieldwork; the Arts and Humanities Research Council for LC's doctoral funding; the NERC Radiocarbon Facility for funding ${ }^{14} \mathrm{C}$ dating (grant number NF/2012/1/7 to TCO'C and LC); and Tom Higham, Diane Baker, Ingmar Unkel, and Elmo Leon for their help and advice.

\section{REFERENCES}

Beresford-Jones DG. 2011. The Lost Woodlands of Ancient Nasca. A Case-Study in Ecological and Cultural Collapse. Oxford: Oxford University Press.

Brock F, Higham TFG, Ditchfield P, Bronk Ramsey C. 2010. Current pretreatment methods for AMS radiocarbon dating at the Oxford Radiocarbon Accelerator Unit (ORAU). Radiocarbon 52(1):103-12.

Bronk Ramsey C. 2001. Development of the radiocarbon calibration program. Radiocarbon 43(2A):355-63.

Bronk Ramsey C. 2009. Bayesian analysis of radiocarbon dates. Radiocarbon 51(1):337-60.

Brown Vega M, Craig NM, Culleton BJ, Kennett DJ, Asencios Lindo G. 2012. AMS radiocarbon dates from Prehispanic fortifications in the Huaura Valley, central coast of Perú. Radiocarbon 55(1):1-12.

Burger RL. 1992. Chavin and the Origins of Andean Civilization. London: Thames and Hudson.

Buzon MR, Conlee CA, Simonetti A, Bowen GJ. 2012. The consequences of Wari contact in the Nasca region during the Middle Horizon: archaeological, skeletal, and isotopic evidence. Journal of Archaeological Science 39(8):2627-36.

Cadwallader L. 2013. Investigating 1500 years of dietary change in the Lower Ica Valley, Peru, using an isotopic approach [ $\mathrm{PhD}$ dissertation]. University of Cambridge.

Cadwallader L, Beresford-Jones DG, Whaley OQ, O'Connell TC. 2012. The signs of maize? A reconsideration of what $\delta^{13} \mathrm{C}$ values say about palaeodiet in the Andean region. Human Ecology 40(4):487509.

Cadwallader L, Arce Torres S, Beresford-Jones DG. In press. Nuevas evidencias de la transición Ocucaje-Nasca en un asentamiento en Samaca, Valle Bajo de Ica, Costa Sur del Perú. In: Peters A, Tomasto E, editors. Paracas - Nasca: Una Época "Transicional" del Formativo Tardio, Costa Sur de los Andes Centrales. Lima: Institut Français d'Etudes Andines (IFEA).

Conlee CA. 2010. Nasca and Wari: local opportunism 
and colonial ties during the Middle Horizon. In: Jennings J, editor. Beyond Wari Walls: Regional Perspectives on Middle Horizon Peru. Albuquerque: University of New Mexico Press. p 96-112.

Cook AG. 1991. Informe final de las investigaciones de reconocimiento en la parte baja del Valle de Ica, 1988-1990 [unpublished manuscript of file]. Lima: Instituto Nacional de Cultura del Perú.

Cook AG. 2004. Wari art and society. In: Silverman HI, editor. Andean Archaeology. Oxford: Blackwell Publishing. p 146-66.

Eitel B, Mächtle B. 2009. Man and environment in the eastern Atacama Desert (southern Peru): Holocene climate changes and their impact on Pre-Columbian cultures. In: Reindel M, Wagner GA, editors. New Technologies for Archaeology: Multidisciplinary Investigations in Papa and Nasca, Peru. Berlin: Springer-Verlag. p 17-23.

Grobman A, Bonavia D, Dillehay TD, Piperno DR, Iriarte J, Holst I. 2012. Preceramic maize from Paredones and Huaca Prieta, Peru. Proceedings of the National Academy of Sciences of the USA 109(5):1755-9.

Hogg A, Bronk Ramsey C, Turney C, Palmer J. 2009. Bayesian evaluation of the Southern Hemisphere radiocarbon offset during the Holocene. Radiocarbon 51(4):1165-76.

Hogg AG, Hua Q, Blackwell PG, Niu M, Buck CE, Guilderson TP, Heaton TJ, Palmer JG, Reimer PJ, Reimer RW, Turney CSM,Zimmerman SRH. 2013. SHCal13 Southern Hemisphere calibration, 0-50,000 years cal BP. Radiocarbon 55(4):1889-903.

Hua Q, Barbetti M, Jacobsen GE, Zoppi U, Lawson EM. 2000. Bomb radiocarbon in annual tree rings from Thailand and Australia. Nuclear Instruments and Methods in Physics Research B 172(1-4):359-65.

Jones KB, Hodgins GWL, Etayo-Cadavid MF, Andrus CFT, Sandweiss DH. 2010. Centuries of marine radiocarbon reservoir age variation within archaeological Mesodesma donacium shells from southern Peru. Radiocarbon 52(3):1207-14.

Kroeber AL, Strong WD. 1924. The Uhle pottery collections from Ica. University of California Publications in American Archaeology and Ethnology 21:95-133.

Lyons P. 1966. Innovation through archaism: the origins of the Ica pottery style. Nawpa Pacha 4:31-64.

Marsh EJ. 2012. A Bayesian re-assessment of the earliest radiocarbon dates from Tiwanaku, Bolivia. Radiocarbon 54(2):203-18.

McCormac FG, Reimer PJ, Hogg AG, Higham TFG, Ballie MGL, Palmer J, Stuiver M. 2002. Calibration of the radiocarbon time scale for the Southern Hemisphere: AD 1850-950. Radiocarbon 44(3):641-51.

Menzel D. 1964. Style and time in the Middle Horizon. Ñawpa Pacha 2:1-106.

Menzel D. 1976. Pottery Style and Society in Ancient Peru. Art as a Mirror of History in the Ica Valley, 1350-1570. Berkeley: University of California Press.

Menzel D, Rowe JH, Dawson LE. 1964. The Paracas
Pottery of Ica: A Study in Style and Time. Berkeley: University of California Press.

Metropolitan Museum of Art [Internet]. On-line catalogue. Accession Number 1979.206.639 [cited 2013 April 15]. Available from http://www.metmuseum. org/Collections.

Pezzia Assereto A. 1968. Ica y el Perú Precolombino: Tomo 1 Arqueología de la Provincia de Ica. Ojeda, Venezuela: Empresa Editora Liberia.

Pollard Rowe A. 1979. Seriation of an Ica-style garment type. In: Pollard Rowe A, Benson EP, Schaffer A-L, editors. The Junius B. Bird Pre-Columbian Textile Conference 1973. Washington, DC: The Textile Museum and Dumbarton Oaks. p 185-218.

Pollard Rowe A. 1992. Provincial Inca tunics of the south coast of Peru. The Textile Museum Journal 31:5-52.

Reimer PJ, Baillie MGL, Bard E, Bayliss A, Beck JW, Blackwell PG, Bronk Ramsey C, Buck CE, Burr GS, Edwards RL, Friedrich M, Grootes PM, Guilderson TP, Hajdas I, Heaton TJ, Hogg AG, Hughen KA, Kaiser KF, Kromer B, McCormac FG, Manning SW, Reimer RW, Richards DA, Southon JR, Talamo S, Turney CSM, van der Plicht J, Weyhenmeyer CE. 2009. IntCa109 and Marine09 radiocarbon age calibration curves, $0-50,000$ years cal BP. Radiocarbon 51(4):1111-50.

Reimer PJ, Bard E, Bayliss A, Beck JW, Blackwell PG, Bronk Ramsey C, Grootes PM, Guilderson TP, Haflidason H, Hajdas I, Hatté C, Heaton TJ, Hoffmann DL, Hogg AG, Hughen KA, Kaiser KF, Kromer B, Manning SW, Niu M, Reimer RW, Richards DA, Scott EM, Southon JR, Staff RA, Turney CSM, van der Plicht J. 2013. IntCal13 and Marine13 radiocarbon age calibration curves $0-50,000$ years cal BP. Radiocarbon 55(4):1869-87.

Rowe JH. 1967. An interpretation of radiocarbon measurements on archaeological samples from Peru. In: Rowe JH, Menzel D, editors. Peruvian Archaeology: Selected Readings. Palo Alto: Peek Publications.

Unkel I, Kromer B. 2009. The clock in the corn cob: on the development of a chronology of the Paracas and Nasca Period based on radiocarbon dating. In: Reindel M, Wagner GA, editors. New Technologies for Archaeology: Multidisciplinary Investigations in Papa and Nasca, Peru. Berlin: Springer-Verlag. p 231-44.

Unkel I, Reindel M, Gorbahn H, Isla J, Kromer B, Sossna V. 2012. A comprehensive numerical chronology for the Pre-Columbian cultures of the Palpa valleys, south coast of Peru. Journal of Archaeological Science 39(7):2294-303.

Vaughn KJ, Eerkens JW, Lipo C, Sakai S, Schreiber K. 2014. It's about time? Testing the Dawson ceramic seriation using luminescence dating, southern Nasca Region, Peru. Latin American Antiquity 25(4):449_ 67.

Worbes M, Junk WJ. 1989. Dating tropical trees by means of ${ }^{14} \mathrm{C}$ from bomb tests. Ecology 70(2):503-7. 